Publisher: LPPM STIE Muhammadiyah Bandung

P-ISSN: 2541-5255, E-ISSN: 2621-5306

Volume 2 Nomor 3, September - Desember 2018

\title{
PENINGKATAN UKM PAKAIAN JADI DI DKI JAKARTA
}

\author{
Miguna Astuti ${ }^{1}$, Nurhafifah Matondang ${ }^{2}$, Agni Rizkita Amanda ${ }^{3}$ \\ Fakultas Ekonomi dan Bisnis \\ Universitas Pembangunan Nasional Veteran Jakarta
}

Jl. RS. Fatmawati No.1 Pondok Labu-Jakarta Selatan 12450 Telp. 021-7656971,

Ext. 234 \& 235, Fax. 021-7656904.

Email: $\underline{\text { miguna.astuti@upnvj.ac.id }}^{1}$, nurhafifahmatondang@yahoo.com $^{2}$

agnirizkitaa@yahoo.com $^{3}$

\begin{abstract}
ABSTRAK
Penelitian yang dilakukan bertujuan untuk mengungkapkan kondisi UKM pakaian di DKI Jakarta dan untuk menangkap strategi terkait untuk peningkatan UKM pakaian di DKI Jakarta berdasarkan pemetaan potensi. Data primer yang digunakan diperoleh dari pengelolaan lokasi bisnis terkonsentrasi yang disediakan oleh pemerintah provinsi yang dikenal sebagai 'lokbin', perwakilan kementerian koperasi dan UKM, pemilik bisnis, konsumen, ahli, dan produsen pakaian di wilayah Jakarta melalui 115 kuesioner. Dengan menggunakan metode sampling proporsional, ada 19 responden dari Jakarta Barat, 24 responden dari Jakarta Utara, 29 responden dari Jakarta Timur, 19 responden dari Jakarta Selatan, dan 24 responden dari Jakarta Pusat. Metode yang digunakan dalam penelitian ini adalah analisis SWOT dan Analytic Hierarchy Process. Hasil yang diperoleh yaitu Strategi prioritas berdasarkan hasil analisa SWOT adalah strategi pada kuadran III, yaitu strategi diversifikasi. Prioritas alternatif strategi diversifikasi berdasarkan hasil analisa AHP, yaitu alternatif strategi diversifikasi konsentris. Prioritas kriteria strategi berdasarkan hasil analisa AHP, yaitu kriteria peluang. Studi ini juga mengeksplorasi pemahaman yang luas tentang UKM pakaian di wilayah DKI Jakarta. Hasil penelitian ini diharapkan bermanfaat untuk pengembangan ilmu pengetahuan, terutama yang berhubungan dengan manajemen, manajemen strategis, dan manajemen pemasaran dan juga dapat bermanfaat bagi pemilik atau pengusaha UKM pakaian, khususnya di Wilayah Jakarta.
\end{abstract}

Kata kunci: UKM Pakaian, SWOT, AHP, Pemetaan Potensial

\section{ABSTRACT}

The conducted study aims to reveal the condition of clothing SMEs in the DKI Jakarta Region and to catch on the related strategy for the improvement of the clothing SMEs in DKI Jakarta based on its potential mapping. The primary data used are obtained from management of the concentrated business location 
provided by the provincial government known as 'lokbin', representatives of ministry of cooperatives and SME's, business owners, consumers, experts, and clothing producers in the Jakarta area through 115 questionnaires. Using the proportioned sampling method, there were 19 respondents from West Jakarta, 24 respondents from North Jakarta, 29 respondents from East Jakarta, 19 respondents from South Jakarta, and 24 respondents from Central Jakarta. The method used in this study is Streght, Weakness, Opportunity and Threat (SWOT) analysis and Analytic Hierarchy Process (AHP). The results obtained from the strategies based on the SWOT analysis are strategies in quadrant III, namely diversification strategies. Preparation of various alternative priority strategies for AHP results, namely alternative concentric diversification strategies. The purpose of the strategy is based on AHP results, namely the concept of opportunity. This study also explores a broad understanding of the clothing SMEs in the DKI Jakarta region. The results of this study are expected to be useful for the development of science, especially related to management, strategic management, and marketing management and also can be of use for the owners or entrepreneurs of clothing SMEs, especially in the Jakarta Region.

Keywords: clothing SMEs, SWOT, AHP, potential mapping

\section{PENDAHULUAN}

Perubahan yang begitu cepat terjadi baik dalam hal teknologi, kebutuhan pelanggan, dan trend produk menyebabkan permasalahan yang serius bagi dunia usaha. Perusahaan dituntut untuk memilih dan menetapkan strategi yang dapat digunakan untuk menghadapi persaingan. Hal tersebut juga berlaku pada usaha mikro kecil dan menengah (UMKM) yang memiliki peran strategis dalam kegiatan pembangunan ekonomi nasional.

Kebijakan Pemerintah DKI Jakarta untuk meningkatkan peran Usaha Kecil Menengah dan Koperasi
(UMKM) perlu ditindak lanjuti dengan analisis dan pemetaan penanggulangan ekonomi lemah. Hal ini berkaitan dengan upaya menggerakkan sektor riil, sehingga ekonomi lemah dapat menjadi lebih kuat dan dapat berperan sebagai mitra bagi usaha menengah dan besar. Ekonomi lemah dapat ditingkatkan peranannya apabila peta permasalahan yang dialaminya dapat diidentifikasi kemudian dibantu dengan program penanggulangan secara komprehensif sehingga pertumbuhannya dapat dirasakan oleh masyarakat paling bawah khususnya masyarakat DKI Jakarta. 
Publisher: LPPM STIE Muhammadiyah Bandung

P-ISSN: 2541-5255, E-ISSN: 2621-5306

Volume 2 Nomor 3, September - Desember 2018

Berdasarkan rencana strategis 2015-2019 Direktorat Jendral Penguatan Riset dan Pengembangan, Pendidikan tinggi berperan penting dalam upaya mencapai kemajuan, meningkatkan daya saing dan membangun keunggulan bangsa melalui pengembangan ilmu pengetahuan, penemuan ilmiah dan teknologi. Sejalan dengan hal tersebut, misi dari UPN "Veteran" Jakarta secara umum, serta Fakultas Ekonomi UPN "Veteran" Jakarta secara khusus adalah menyelenggarakan Tridharma perguruan tinggi berkualitas di bidang ekonomi dan bisnis dengan basis teknologi informasi dengan turut berpartisipasi aktif dalam pembangunan nasional. (LPPM UPN Veteran Jakarta, 2015)

\section{Berdasarkan}

penelitian

Hidayati, et al (2017) permasalahan yang sering kali dihadapi usaha kecil dan menengah sangat beragam. Oleh karena itu perlu pengkajian yang lebih mendalam untuk mengidentifikasi dan memetakan kondisi serta permasalahan utama yang sebenarnya (Badan Pusat Statistik, 2016)
Lebih lanjut menurut Berry (2001) menyatakan bahwa Peran Usaha Mikro, Kecil dan Menengah (UMKM) sangat penting dan diperlukan terutama dalam pembangunan ekonomi daerah terutama Usaha Kecil dan Mikro (UKM). Hal ini terdapat 3 alasan utama. Pertama, kinerja UKM cenderung lebih baik dalam menghasilkan tenaga kerja yang produktif. Kedua, UKM sering meningkatkan produktivitasnya melalui investasi dan aktif mengikuti perubahan teknologi. Ketiga, UKM diyakini memiliki keunggulan dalam fleksibilitas dibandingkan usaha besar.

Kementerian Koperasi dan UKM terus melakukan perubahan, sehingga berdampak besar meningkatnya produk domestik bruto sampai 2013 PDB Koperasi 1,71\%, dalam waktu 2 tahun PDB Koperasi meningkat menjadi 4\% tepatnya $3,99 \%$. rasio kewirausahaan yang selama ini sampai tahun 2013 hanya $1,55 \%$ dan pada 2016 meningkat menjadi 3,01\%, dengan rasio kewirausahaannya secara internasional minimal $2 \%$ dari jumlah penduduk. Makin hari, UKM 
dan Koperasi makin kekinian, bahkan menjangkau anak-anak muda. Dengan banyaknya tenaga kerja yang diserap, Kamar Dagang dan Industri Indonesia (Kadin) menilai sektor UMKM mampu meningkatkan pendapatan masyarakat. Dengan demikian, UMKM dianggap memiliki peran strategis dalam memerangi kemiskinan, dan pengangguran. (Retno Hemawati, 2017)

Badan Pusat Statistik (BPS,2017) menyatakan bahwa Pada tahun 2015 jumlah perusahaan industri manufaktur besar dan sedang di provinsi DKI Jakarta sebanyak 1.323 perusahaan. Dari berbagai jenis industry yang disurvei oleh badan pusat statistic DKI Jakarta, jenis industry pakaian jadi memiliki kuantitas terbesar dengan jumlah mencapai 281 perusahaan atau sebesar 21,24\% dari seluruh jumlah perusahaan industry manufaktur sedang dan besar. Penyerapan tenaga kerja secara umum sebanyak 277.597 orang terdiri dari tenaga kerja produksi sebanyak 223.772 orang, tenaga kerja lainnya sebanyak 53.825 orang. Berdasarkan jumlah tenaga kerja, industry pakaian jadi paling banyak menyerap tenaga kerja yaitu sebanyak 62.402 orang. Imbalan seluruh pekerja perusahaan industry manufaktur besar dan sedang tercatat sebesar 14,95 triliun rupiah.

UKM sendiri berada dibawah naungan Dinas KUMKM diatur dengan instruksi Guberbur DKI Jakarta No.170 tahun 2014 dengan pembahasan percepatan pendataan dan pendaftaran para pedagang kaki lima dengan tujuan untuk membantu para pelaku UKM mendapatkan lokasi usaha sebagai bentuk pembinaan UMKM di DKI Jakarta. Dalam rangkaian penataan secara operasional, lokasi PKL sesuai keputusan gubernur Prov. DKI Jakarta No.11 Tahun 2004, lokasi PKL dapat dikelompokan sebagai berikut: (a). lokasi binaan (lokbin); (b) lokasi sementara; (c) lokasi terjadwal; (d) lokasi terkendali dan (e) lokasi tidak resmi.

Berdasarkan uraian di atas maka peneliti tertarik untuk melakukan penelitian lebih lanjut guna mengetahui kondisi dan strategi UKM di DKI Jakarta secara menyeluruh, sehingga peneliti akan melakukan penelitian dengan judul 
Publisher: LPPM STIE Muhammadiyah Bandung

P-ISSN: 2541-5255, E-ISSN: 2621-5306

Volume 2 Nomor 3, September - Desember 2018

"Peningkatan UKM Pakaian Jadi di DKI Jakarta".

Berdasarkan latar belakang yang telah diuraikan, maka dapat dirumuskan masalah penelitian yaitu Bagaimana kondisi UKM Pakaian Jadi di Wilayah DKI Jakarta dan Bagaimana strategi peningkatan UKM pakaian jadi di DKI Jakarta berdasarkan potensi yang dimiliki.

\section{TINJAUAN PUSTAKA}

\section{Penelitian Terdahulu}

Purnomo \& Hadi (2017) dalam penelitiannya dengan judul "Pengukuran Kinerja UMKM Menggunakan Performance Firm". Penelitian ini bertujuan untuk melakukan pengukuran kinerja yang dilakukan hanya berdasarkan Net Profit Margin tiap tahunnya. Pengumpulan data dilakukan dengan melakukan wawancara yang dilakukan selama dua tahun terakhir. Metode yang digunakan adalah metode Analytical Hierarchy Process (AHP). Pengukuran kinerja dengan metode performance firm. Hardiyansyah dkk (2015) dalam penelitiannya dengan judul "Analisis Strategi Pemasaran Usaha Mie Basah (Studi Kasus di PD. Lugina-Garut).
Tujuan dalam penelitian ini adalah mengidentifikasi kekuatan, kelemahan, peluang dan ancaman perusahaan, kemudian menentukan strategi perusahaan perusahaan berdasarkan faktor eksternal dan internal perusahaan setelah itu mendapatkan prioritas strategi yang diterapkan. Penelitian ini menggunakan penggabungan metode Analytical Hierarchy Process (AHP), matriks IFE\&EFE serta analisis SWOT. Dari hasil analisa diketahui bahwa prioritas strategi yang dapat digunakan PD. Lugina dalam menjalankan usahanya adalah dengan memperbaiki system manajemen.

Supriatna \& Aminah (2014) dalam penelitiannya dengan judul “Analisis Strategi Pengembangan Usaha Kopi Luwak (Studi Kasus UMKM Careuh Coffe RancabaliCiwidey Bandung). Tujuan dalam penelitian ini adalah untuk mengetahui bauran pemasaran yang telah diterapkan oleh UMKM Careuh Coffe, mengidentifikasi dan menganalisis faktor-faktor lingkungan internal dan eksternal yang mempengaruhi strategi UMKM Careuh Coffe, menyusun dan 
Publisher: LPPM STIE Muhammadiyah Bandung

P-ISSN: 2541-5255, E-ISSN: 2621-5306

Volume 2 Nomor 3, September - Desember 2018

merekomendasikan

alternative

strategi yang efektif dan efisien

untuk UMKM Coffe. Penelitian ini menggunakan Metode Analytical

Hierarchy Process.

Nasution \& Hidayat (2014) dalam penlitiannya dengan judul “Analisis Strategi Pengembangan Koperasi di Kota Medan Dengan Metode Analisis SWOT dan Analytical Hierarchy Process (AHP). Tujuan penelitian ini untuk mengetahui strategi pengembangan koperasi di kota medan. Lokasi penelitian ini dilakukan di Dinas KUMKM kota Medan dengan teknik pengumpulan data melalui observasi dan wawancara dengan kepala dinas KUMKM kota Medan, Kepala Seksi Koperasi, Pelaku Koperasi di Kota Medan dan Pakar koperasi atau pengamat koperasi, informasi yang diberikan menjadi saran dan masukan yang bersifat kualitatif. Metode analysis yang digunakan adalah menggunakan pendekatan analisis SWOT dan pendekatan Analytical Hierarchy Process (AHP)

\section{Usaha Kecil dan Menengah (UKM)}

Menurut Tambunan (2012, hlm. 11) menyatakan bahwa UKM adalah unit usaha produktif yang berdiri sendiri, yang dilakukan oleh orang perorangan atau badan usaha di semua sektor ekonomi.

Berdasarkan Undang - Undang No. 20 Tahun 2008 BAB I Pasal 1 ayat 1 s/d 3, tentang Usaha Kecil dan Menengah (UKM) dalam buku Basri dan Nugroho (2009, hlm. 34), dan buku Tambunan (2012, hlm. 14), mendefinisikan sebagai berikut:

a). Usaha kecil adalah usaha ekonomi produktif yang berdiri sendiri, yang dilakukan oleh orang perorangan atau badan usaha yang bukan merupakan anak perusahaan atau bukan cabang perusahaan yang dimiliki, dikuasai, atau menjadi bagian baik langsung maupun tidak langsung dari usaha menengah atau usaha besar yang mememnuhi kriteria usaha kecil sebagaimana dimaksud dalam undang undang.

b). Usaha menengah adalah usaha ekonomi produktif yang berdiri sendiri, yang dilakukan oleh orang 


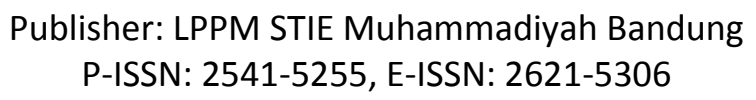

Volume 2 Nomor 3, September - Desember 2018

perorangan atau badan usaha yang bukan merupakan anak perusahaan atau cabang perusahaan yang dimiliki, dikuasai, atau menjadi bagian baik langsung maupun tidak langsung dengan usaha kecil atau usaha besar dengan jumlah kekayaan bersih atau hasil penjualan tahunan sebagaimana diatur dalam Undang - Undang ini.

Berdasarkan Undang - Undang No. 20 Tahun 2008 BAB IV Pasal 6 ayat 1 s/d 3 tentang Usaha Kecil dan Menengah (UKM) masing - masing dalam buku Basri dan Nugroho (2009, hlm 35), buku Tambunan (2012, hlm. 18) dan buku Saiman (2014, hlm. 2014), definisi dan kriteria usaha dan kriteria usaha mikro, kecil, dan menengah adalah sebagai berikut:

Tabel 2.1 Kriteria UKM

\begin{tabular}{|l|l|l|}
\hline Kriteria & Usaha Kecil & Usaha Menengah \\
\hline Bentuk Usaha & $\begin{array}{l}\text { Perseorangan badan usaha } \\
\text { Bukan afiliasi usaha }\end{array}$ & $\begin{array}{l}\text { Perseorangand badan usaha } \\
\text { Bukan afiliasi usaha besar }\end{array}$ \\
\hline Kekayaan bersih & $\begin{array}{l}\text { Rp. 50 juta - Rp, 500 juta, } \\
\text { tidak termasuk tanah dan } \\
\text { bangunan }\end{array}$ & $\begin{array}{l}\text { Rp. 500 juta - Rp. 10 } \\
\text { miliar, tidak termasuk } \\
\text { tanah dan bangunan }\end{array}$ \\
\hline Omzet tahunan & $\begin{array}{l}\text { Rp. 300 juta - Rp. 2,5 } \\
\text { miliar }\end{array}$ & $\begin{array}{l}\text { Rp. 2,5 miliar - Rp. 50 } \\
\text { miliar }\end{array}$ \\
\hline
\end{tabular}

Basri dan Nugroho (2009, hlm. 34)

\section{Analisis Lingkungan}

\section{Analisis Internal}

Pengelolaan yang baik dapat dilihat dari beberapa factor yang dapat diidentifikasi dalam lingkungan internal perusahaan (David, 2015).

a. Sumber Daya Manusia, yaitu suatu proses untuk memperoleh, melatih, menilai dan memberikan kompensasi kepada karyawan, serta memperhatikan hubungan kerja dengan Karyawan.

b. Keuangan, yaitu keputusan investasi dan keputusan pembiayaan

c. Produksi dan Operasi, yaitu semua aktivitas yang mengubah input (kemampuan) melalui proses transformasi (penerapan kemampuan) dan menghasilkan output

d. Pemasaran, yaitu analisa pelanggan, penjualan produk atau jasa, penetapan harga dan distribusi.

\section{Analisis Eksternal}

Dalam pengembangan usaha juga melihat lingkungan eksternal, yang diperlukan untuk mengetahui factor-faktor yang dapat memberikan 
peluang dan ancaman bagi perusahaan. Lingkungan eksternal itu sendiri menurut Michael Porter dalam teori lima kekuatan Porter terdiri dari:

a. Ancaman pendatang baru

Faktor penghambat pendatang baru antara lain skala ekonomis, deferensiasi produk, kebutuhan modal, biaya beralih ke pemasok, akses saluran distribusi dan biaya tak menguntungkan terlepas dari skala.

b. Kekuatan tawar menawar pemasok

Pemasok memiliki daya tawar yang kuat apabila pemasok didominasi oleh beberapa perusahaan, pemasok tidak bersaing dengan produk-produk lain dalam industry, industry bukan pelanggan yang pernting bagi pemasok.

c. Kekuatan tawar menawar pembeli Pelanggan memiliki kemampuan untuk menekan dan menurunkan harga produk serta meningkatkan pelayanan. Kelompok pembeli dikatakan kuat jika kelompok pembeli terpusat, produk tidak terdeferensiasi, pembeli mendapat laba kecil, pembeli memiliki informasi lengkap.

d. Ancaman produk subtitusi

Produk pengganti yang kualitasnya hampir sama menawarkan harga yang relative murah. Produk subtitusi yang perlu mendapat perhatian adalah produk yang kualitasnya menandingi kualitas produk, bahkan lebih tinggi.

Persaingan diantara para anggota industry. Persaingan diantara anggota industry karena perebutan posisi dan dilakukan dengan melakukan strategi. Persaingan tersebut disebabkan oleh jumlah pesaing, pertumbuhan industri, karakteristik produk, biaya tetap yang besar, kapasitas dan hambatan keluar.

\section{TAHAPAN PENELITIAN}

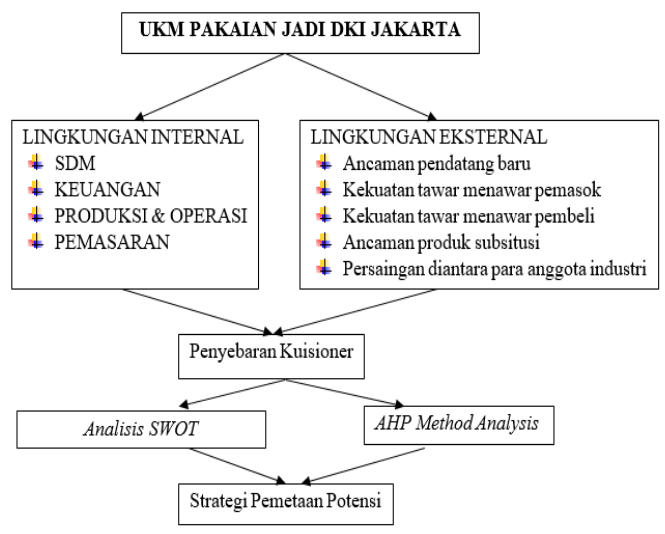


Publisher: LPPM STIE Muhammadiyah Bandung

P-ISSN: 2541-5255, E-ISSN: 2621-5306

Volume 2 Nomor 3, September - Desember 2018

Gambar 3.1 Tahapan Penelitian

\section{METODE PENELITIAN}

\section{Metode Penelitian}

Pendekatan serta tehnik

Analisa pada penelitian ini menggunakan pendekatan rasionalistik dengan memperhatikan terlebih dahulu hal-hal umum menuju ke hal khusus sebagai dasar analisa suatu masalah.

\section{Sumber dan Teknik Pengumpulan Data}

Penelitian ini menggunakan teknik analisis kuantitatif dan kualitatif (mixed method) yang fokus pada kondisi lapangan dan masyarakat. Sesuai wilayah penelitian, yaitu DKI Jakarta Teknik analisis ini lebih menekankan pada aspek pemahaman secara mendalam terhadap suatu masalah daripada melihat permasalahan untuk penelitian generalisasi. Metode penelitian ini lebih menggunakan teknik analisis mendalam (in-depth analysis), yaitu mengkaji masalah secara kasus perkasus. (Elvinaro, 2010).

\section{Jenis Data}

Jenis data yang digunakan pada penelitian ini yaitu data primer dan data sekunder. Data primer dalam pengambilan data dengan melakukan penyebaran kuisioner, dokumentasi, wawancara, sedangkan data sekunder dalam pengambilan data dengan melakukan observasi dan studi literature

\section{Populasi dan Sampel}

Poulasi dari penelitian ini adalah Pengusaha UKM Pakaian Jadi berskala kecil dan menengah yang berada di wilayah DKI Jakarta dan sampel yang dipilih dalam penelitian ini adalah penjaga lokbin, dinas Koperasi dan UMKM, Pemilik Usaha, konsumen, Pakar, Produsen.

Dalam pengambilan sampel peneliti menggunakan stratified purposive sampling dengan kriteria, sampel yang digunakan dalam penelitian ini sebanyak 115 sampel yang terdiri dari perwakilan pengelola dari masing-masing lokbin, perwakilan kepala dinas KUMKM dan Koperasi di 5 wilayah DKI Jakarta, perwakilan kepala dinas KUMKM dan Koperasi wilayah 
provinsi DKI Jakarta, pemilik usaha, konsumen, pakar dan produsen.

\section{TEKNIK ANALISIS DATA}

\section{Analisis SWOT}

Tahapan-tahapan yang dilakukan pada analisa SWOT ini adalah sebagai berikut:

1. Menentukan masing-masing indikator kekuatan, kelemahan, ancaman dan kekuatan yang akan di masukkan ke dalam matriks IFE dan ke dalam matriks EFE.

2. Menyebarkan kuisioner untuk mengetahui bobot responden terhadap masing-masing indikator kekuatan, kelemahan, ancaman dan kekuatan dengan skala 1 hingga 5.

3. Menyebarkan kuisioner untuk mengetahui ranking responden terhadap masing-masing indikator kekuatan, kelemahan, ancaman dan kekuatandengan skala 1 hingga 4.

4. Merekap data responden ke dalam program Excel.

5. Mengolah data responden yang telah di reduksi ke dalam matriks IFE dan EFE untuk mengetahui hasil perkalian antara bobot dengan rating sehingga diperoleh nilai kekuatan dan nilai kelemahan pada matriks IFE dan nilai peluang dan nilai ancaman pada matriks EFE serta ranking dari masing-masing indikator kekuatan, kelemahan, ancaman dan kekuatan.

6. Melakukan perhitungan kordinat internal dan kordinat eksternal dan memasukkan kordinat tersebut ke dalam matriks grand strategy (GS) atau yang seringkali disebut dengan strategi besar. Matriks GS ini terbagi menjadi 4 (empat) kuadran, yaitu:

a. Kuadran I: dikenal dengan kuadran pertumbuhan karena internal usaha kuat dan lingkungan mendukung. Dengan ini usaha dapat mengambil keuntungan dari peluang yang muncul dengan sumber daya kuat yang dimiliki.

b. Kuadran II: dikenal dengan kuadran stabilitas/bertahan karena internal usaha lemah meski lingkungan mendukung. Sehingga meski industri tersebut tengah bertumbuh, namun usaha tidak mampu bersaing secara efektif.

c. Kuadran III: dikenal dengan kuadran penciutan karena 
internal usaha yang lemah dan lingkungan yang kurang mendukung. Sehingga harus segera membuat perubahan yang drastis untuk menghindari penurunan lebih jauh.

d. Kuadran IV: dikenal dengan kuadran kombinasi/diversifikasi karena internal usaha kuat namun lingkungan kurang mendukung. Sehingga dapat melakukan program diversifikasi ke pasar yang lebih menjanjikan.m

7. Menghitung luasan matriks untuk mendapatkan prioritas strategi.

8. Mencocokkan prioritas strategi berdasarkan posisi pada matriks GS dengan urutan prioritas berdasarkan perhitungan perluasan matrik

\section{Analytic Hierarchy Process (AHP)}

Metode Analytic Hierarchy Process (AHP) dikembangkan oleh Thomas L. Saaty pada tahun 70-an ketika di Warston school. Metode AHP merupakan salah satu metode yang dapat digunakan dalam sistem pengambilan keputusan dengan memperhatikan faktor - faktor persepsi, preferensi, pengalaman dan intuisi. AHP menggabungkan penilaian - penilaian dan nilai - nilai pribadi ke dalam satu cara yang logis.

Metode ini adalah sebuah kerangka untuk mengambil keputusan dengan efektif atas persoalan dengan menyederhanakan dan mempercepat proses pengambilan keputusan dengan memecahkan persoalan tersebut kedalam bagian - bagiannya, menata bagian atau variabel ini dalam suatu susunan hirarki, memberi nilai numerik pada pertimbangan subjektif tentang pentingnya tiap variabel dan mensintesis berbagai pertimbangan ini untuk menetapkan variabel yang mana yang memiliki prioritas paling tinggi dan bertindak untuk mempengaruhi hasil pada situasi tersebut. Metode ini juga menggabungkan kekuatan dari perasaan dan logika yang bersangkutan pada berbagai persoalan, lalu mensintesis berbagai pertimbangan yang beragam menjadi hasil yang cocok dengan perkiraan kita secara intuitif sebagaimana yang dipersentasikan pada pertimbangan yang telah dibuat. 
Publisher: LPPM STIE Muhammadiyah Bandung

P-ISSN: 2541-5255, E-ISSN: 2621-5306

Volume 2 Nomor 3, September - Desember 2018

Tahapan-Tahapan

Pengambilan

\section{Keputusan AHP}

$\begin{array}{llr}\text { Tahapan } & - & \text { tahapan } \\ \text { pengambilan keputusan } & \text { dalam } \\ \text { metode AHP pada dasarnya } & \text { adalah } \\ \text { sebagai berikut: } & & \\ \text { 1. Mendefenisikan } & \text { masalah } & \text { dan } \\ \text { menentukan } & \text { solusi } & \text { yang } \\ \text { diinginkan. } & & \end{array}$

2. Membuat struktur hirarki yang diawali dengan tujuan umum, dilanjutkan dengan kriteriakriteria dan alternatif - alternatif pilihan yang ingin di rangking.

3. Membentuk matriks perbandingan berpasangan yang menggambarkan kontribusi relatif atau pengaruh setiap elemen terhadap masing-masing tujuan atau kriteria yang setingkat diatas. Perbandingan dilakukan berdasarkan pilihan atau judgement dari pembuat keputusan dengan menilai tingkattingkat kepentingan suatu elemen dibandingkan elemen lainnya.

4. Menormalkan data yaitu dengan membagi nilai dari setiap elemen di dalam matriks yang berpasangan dengan nilai total dari setiap kolom.
5. Menghitung nilai eigen vector dan menguji konsistensinya, jika tidak konsisten maka pengambilan data (preferensi) perlu diulangi. Nilai eigen vector yang dimaksud adalah nilai eigen vector maksimum yang diperoleh dengan menggunakan matlab maupun dengan manual.

6. Mengulangi langkah, 3, 4, dan 5 untuk seluruh tingkat hirarki.

7. Menghitung eigen vector dari setiap matriks perbandingan berpasangan. Nilai eigen vector merupakan bobot setiap elemen. Langkah ini untuk mensintetis pilihan dalam penentuan prioritas elemen pada tingkat hirarki terendah sampai pencapaian tujuan.

8. Menguji konsistensi hirarki. Jika tidak memenuhi dengan $\mathrm{CR}<$ 0,100 maka penilaian harus diulangi kembali.

\section{HASIL DAN DISKUSI}

\section{Hasil Yang Dicapai}

Uraian dan pembahasan atas temuan yang didapatkan dari lapangan akan ditampilkan dibagian ini. Rumusan masalah yang sudah disampaikan dalam rumusan 
Publisher: LPPM STIE Muhammadiyah Bandung

P-ISSN: 2541-5255, E-ISSN: 2621-5306

Volume 2 Nomor 3, September - Desember 2018

masalah, akan dijawab berdasarkan metode yang sudah disampaikan dengan dukungan teori.

\section{Gambaran Umum Objek Penelitian}

Pemerintah DKI berupaya untuk mengatur mereka dengan cara membagi UMKM menjadi dua kelompok, yaitu a). Usaha Kecil dan Menengah (UKM) b). Industri Kecil dan Menengah (IKM), hal ini yang membedakan pengelompokan UMKM di DKI berbeda dengan wilayah lain.

UKM berada dibawah naungan Dinas Koperasi, UKM dan Perdagangan. UKM diatur dengan Instruksi Gubernur Provinsi Daerah Khusus Ibukota Jakarta No. 170 tahun 2014 tentang Percepatan Pendataan dan Pendaftaran Para Pedagang Kaki Lima, sedangkan IKM dibawah naungan Dinas Perindustrian dan Energi, IKM diatur dengan Instruksi Gubernur No.208 Tujuannya adalah untuk membantu para pelaku UKM dan dan IKM mendapatkan lokasi usaha, sebagai bentuk pembinaan UMKM di DKI Jakarta. Khusus pelaku UKM, lokasi usaha dibagi menjadi dua, yaitu : a).
Lokasi Binaan (Lokbin) dan b) Lokasi Sementara (Loksem). (Hidayati dkk)

Lokasi Binaan (Lokbin) adalah tempat usaha yang disediakan oleh Pemerintah DKI. Keuntungan yang didapat oleh pelaku UKM di Lokbin adalah dengan biaya sewa yang murah, yaitu hanya dengan membayar biaya retribusi sebesar Rp.4.000,- (empat ribu rupiah) per hari dengan cara pembayaran auto debet melalui Bank DKI, atau khusus untuk Lokbin.

Lokasi Sementara (Loksem), tempat ini hanya bersifat sementara, disediakan Pemerintah DKI, dengan tujuan membantu para Pedadang Kaki Lima (PKL) untuk sementara sampai pelaku usaha mampu mengembangkan usahanya, sehingga pelaku usaha dapat pindah ke Lokbin atau ke lokasi permanen. Loksem suatu saat dapat dibubarkan oleh Pemerintah Provinsi DKI, karena digunakan untuk kepentingan umum.

Berdasarkan data yang diperoleh peneliti dari berbagai SUDIN UKM dan DINAS IKM di 5 (lima) wilayah DKI Jakarta diketahui bahwa terdapat 31.137 pengusaha IKM dan UKM. Jumlah masing- 
Publisher: LPPM STIE Muhammadiyah Bandung

P-ISSN: 2541-5255, E-ISSN: 2621-5306

Volume 2 Nomor 3, September - Desember 2018

masing IKM dan UKM secara keseluruhan serta jumlah populasi target yang digunakan seperti terlihat pada Tabel berikut.

Tabel 6.1 Data UKM dan UKM DKI Jakarta

\begin{tabular}{|l|l|l|}
\hline \multirow{2}{*}{ Wilayah } & \multicolumn{2}{c|}{ Populasi } \\
\cline { 2 - 3 } & \multicolumn{1}{|c|}{ IKM } & UKM \\
\hline Jakbar & 7,105 & 742 \\
\hline Jakpus & 5,325 & 570 \\
\hline Jaksel & 4,264 & 544 \\
\hline Jaktim & 6,299 & 524 \\
\hline Jakut & 5,313 & 451 \\
\hline \multirow{2}{*}{ TOTAL } & 28,306 & 2,831 \\
\cline { 2 - 3 } & 31,137 \\
\hline
\end{tabular}

Masyarakat DKI Jakarta dalam memenuhi kebutuhan fashion agar masyarakat tidak lari keluar wilayah DKI. Jika semua kebutuhan masyarakat akan barang yang diinginkannya dapat disediakan oleh UMKM maka keberadaan UMKM juga akan berkontribusi meningkatkan sumber pendapatan daerah.

Kesesuaian data yang diperoleh dari SUDIN UKM dan IKM DKI Jakarta dengan keadaan lapangan menjadi kendala lain bagi peneliti dalam menyebarkan kuisioner, dimana nama usaha serta alamat yang tercantum pada data mayoritas berbeda dengan keadaan di lapangan.
Dari total 763 data UKM produk fashion di DKI Jakarta, hanya terdapat kurang dari $50 \% \quad$ (215 usaha) yang nama serta alamat usaha sesuai dengan data SUDIN. Sisa responden lainnya, peneliti peroleh dari usaha dengan karakteristik serupa yang berada di sekitar LOKBIN masing-masing wilayah di DKI Jakarta.

Pengusaha UKM Pakaian Jadi berskala kecil dan menengah yang berada di wilayah DKI Jakarta terdiri penjaga lokbin, dinas Koperasi dan UMKM, Pemilik Usaha, konsumen, Pakar, Produsen.

\section{Gambaran Data Responden}

Pada sub bab ini akan dibahas pembagian wilayah lokasi binaan dan karakteristik dari pemilik atau pengelola dari pengusaha UKM pakaian jadi.

\section{A. UKM Pakaian Jadi Wilayah Jakarta Barat}

Responden dalam penelitian ini dikelompokkan menjadi beberapa lokasi yaitu Meruya Ilir, Rawa Buaya dan Bangun Nusa. Masing-masing 2 responden setiap lokasi binaan, responden yang dituju adalah 
Pemilik, Konsumen, Pegawai Lokbin, Kadis Wilayah, dan Kadis Provinsi. Sehingga responden yang diperoleh pada wilayah Jakarta Barat sebanyak 19 responden yang memiliki karakteristik sebagai berikut:

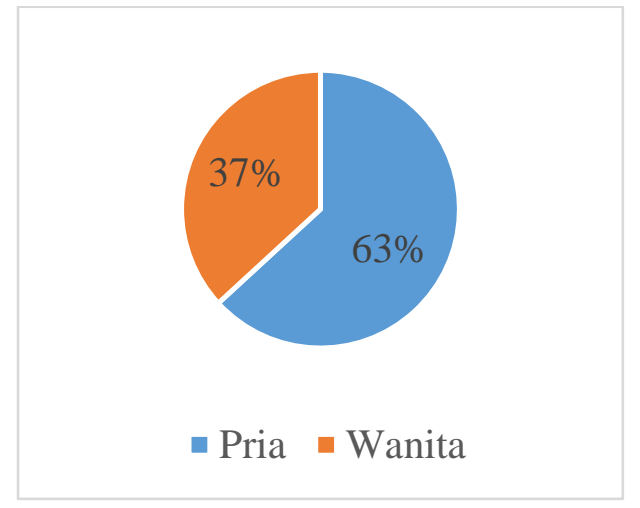

Sumber: Hasil Olah Data, 2018 Gambar 6.1 Karakteristik Responden UKM Pakaian Jadi Wilayah Jakarta Barat Berdasarkan Jenis Kelamin

Gambar $\quad 6.1 \quad$ diatas menggambarkan bahwa UKM pakaian jadi di wilayah Jakarta barat lebih banyak responden yang berjenis kelamin pria yaitu sebesar 63\% atau sebesar 12 dari 19 Responden dibandingan responden yang berjenis kelamin wanita yaitu sebesar $37 \%$ atau 12 dari 19 responden.

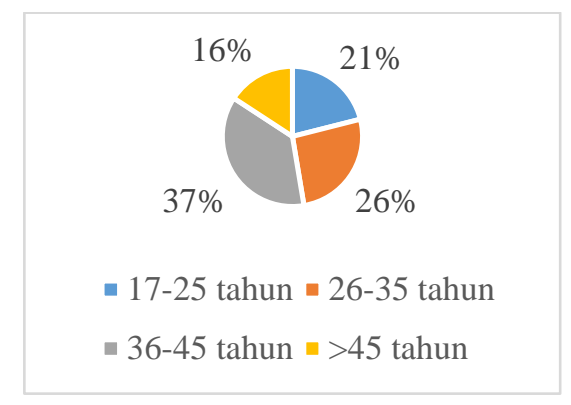

Sumber: Hasil Olah Data, 2018 Gambar 6.2 Karakteristik Responden UKM Pakaian Jadi Wilayah Jakarta Barat Berdasarkan Jenis Kelamin Usia

Gambar $\quad 6.2$ di atas menunjukan bahwa jumlah responden berdasarkan tingkatan usia dikelompokan menjadi 4 kategori yaitu: usia 17-25 tahun sebanyak 4 orang (21\%), usia 26-35 tahun sebanyak 5 orang (26\%), usia 36-45 tahun sebanyak 7 orang (37\%) dan usia >45 tahun sebanyak 3 orang (16\%). Sehingga responden yang berusia 36-45 tahun lebih mendominasi pada wilayah Jakarta barat dalam hal responden UKM Pakaian jadi.

\section{B. UKM Pakaian Jadi Wilayah Jakarta Utara}

Responden dalam penelitian ini dikelompokkan menjadi beberapa lokasi yaitu Tipar, Lorong 103 Blok A, Lorong 103 Blok B, Lorong 103 Blok C. Masing-masing 2 responden setiap lokasi binaan, responden yang 
Publisher: LPPM STIE Muhammadiyah Bandung

P-ISSN: 2541-5255, E-ISSN: 2621-5306

Volume 2 Nomor 3, September - Desember 2018

dituju adalah Pemilik, Konsumen, Pegawai Lokbin, Kadis Wilayah, dan Kadis Provinsi. Sehingga responden yang diperoleh pada wilayah Jakarta Utara sebanyak 24 responden yang memiliki karakteristik sebagai berikut:

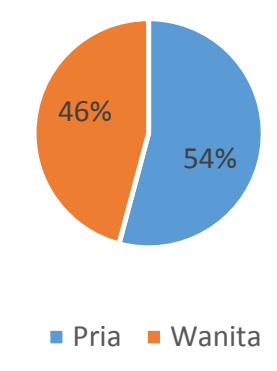

Sumber: Hasil Olah Data, 2018 Gambar 6.3 Karakteristik Responden UKM Pakaian Jadi Wilayah Jakarta Utara Berdasarkan Jenis Kelamin

Gambar $\quad 6.3 \quad$ diatas menggambarkan bahwa UKM pakaian jadi di wilayah Jakarta Utara lebih banyak responden yang berjenis kelamin pria yaitu sebesar $54 \%$ atau sebesar 13 dari 24 Responden dibandingan responden yang berjenis kelamin wanita yaitu sebesar $46 \%$ atau 11 dari 24 responden.

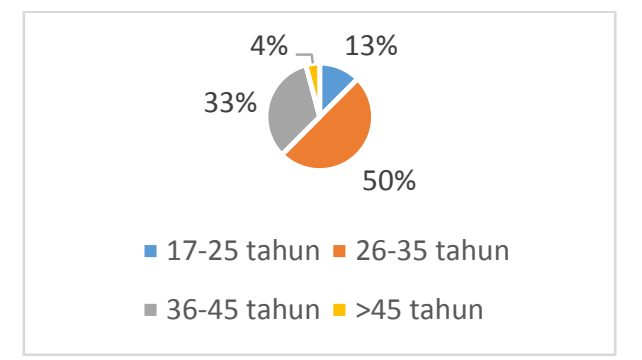

Sumber: Hasil Olah Data, 2018

\begin{abstract}
Gambar 6.4 Karakteristik Responden UKM Pakaian Jadi Wilayah Jakarta Utara Berdasarkan Jenis Kelamin Usia Gambar 6.4 di atas menunjukan bahwa jumlah
\end{abstract} responden berdasarkan tingkatan usia dikelompokan menjadi 4 kategori yaitu: usia 17-25 tahun sebanyak 3 orang (13\%), usia 26-35 tahun sebanyak 12 orang (50\%), usia 36-45 tahun sebanyak 8 orang (33\%) dan usia $>45$ tahun sebanyak 1 orang $(4 \%)$. Sehingga responden yang berusia 26-35 tahun lebih mendominasi pada wilayah Jakarta Utara dalam hal responden UKM Pakaian jadi.

\section{UKM Pakaian Jadi Wilayah Jakarta Timur}

Responden dalam penelitian ini dikelompokkan menjadi beberapa lokasi yaitu Cililitan, Kramat Jati, Jalan Nusa, Makasar dan Munjul . Masing-masing 2 responden setiap lokasi binaan, responden yang dituju adalah Pemilik,Konsumen, Pegawai Lokbin, Kadis Wilayah, dan Kadis Provinsi. Sehingga responden yang diperoleh pada wilayah Jakarta Timur sebanyak 29 responden yang memiliki karakteristik sebagai berikut: 


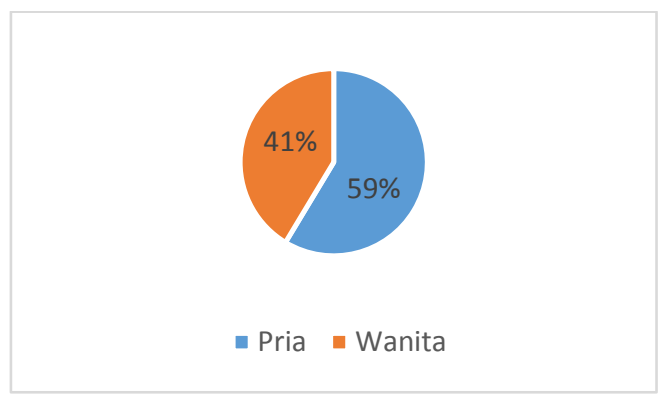

Sumber: Hasil Olah Data, 2018 Gambar 6.5 Karakteristik Responden UKM Pakaian Jadi Wilayah Jakarta Timur Berdasarkan Jenis Kelamin

Gambar $\quad 6.5 \quad$ diatas menggambarkan bahwa UKM pakaian jadi di wilayah Jakarta Timur lebih banyak responden yang berjenis kelamin pria yaitu sebesar $59 \%$ atau sebesar 17 dari 29 Responden dibandingan responden yang berjenis kelamin wanita yaitu sebesar $41 \%$ atau 12 dari 29 responden.

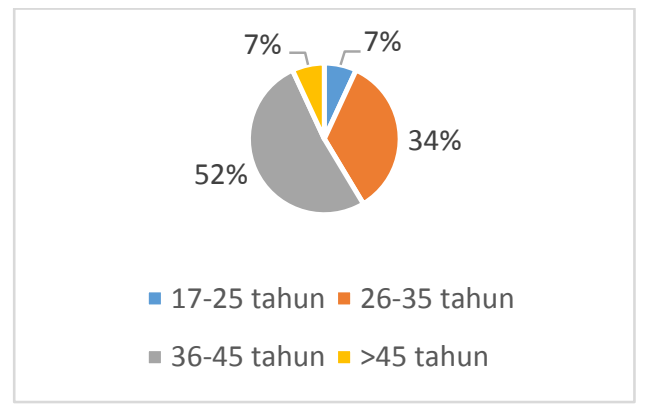

Sumber: Hasil Olah Data, 2018 Gambar 6.6 Karakteristik Responden UKM Pakaian Jadi

Wilayah Jakarta Timur Berdasarkan Jenis Kelamin Usia

Gambar $\quad 6.6 \quad$ di atas menunjukan bahwa jumlah responden berdasarkan tingkatan usia dikelompokan menjadi 4 kategori yaitu: usia 17-25 tahun sebanyak 2 orang (7\%), usia 26-35 tahun sebanyak 10 orang (34\%), usia 36-45 tahun sebanyak 15 orang (52\%) dan usia >45 tahun sebanyak 2 orang $(7 \%)$. Sehingga responden yang berusia 36-45 tahun lebih mendominasi. Dapat disimpulkan bahwa usia 36-45 tahun pada wilayah Jakarta Timur dalam hal responden UKM Pakaian jadi.

\section{UKM Pakaian Jadi Wilayah Jakarta Selatan}

Responden dalam penelitian ini dikelompokkan menjadi beberapa lokasi yaitu Muria Dalam, Pasar Minggu dan Bintaro . Masingmasing 2 responden setiap lokasi binaan, responden yang dituju adalah Pemilik,Konsumen, Pegawai Lokbin, Kadis Wilayah, dan Kadis Provinsi. Sehingga responden yang diperoleh pada wilayah Jakarta Selatan sebanyak 19 responden yang memiliki karakteristik sebagai berikut: 
Publisher: LPPM STIE Muhammadiyah Bandung

P-ISSN: 2541-5255, E-ISSN: 2621-5306

Volume 2 Nomor 3, September - Desember 2018

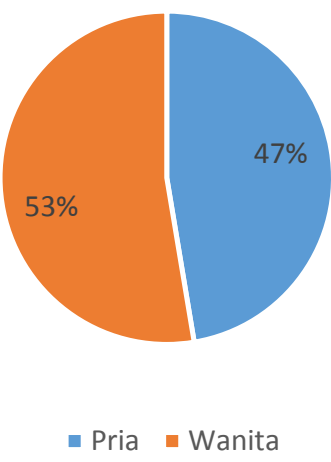

Sumber: Hasil Olah Data, 2018 Gambar 6.7 Karakteristik Responden UKM Pakaian Jadi Wilayah Jakarta Selatan Berdasarkan Jenis Kelamin

Gambar $\quad 6.7 \quad$ diatas menggambarkan bahwa UKM pakaian jadi di wilayah Jakarta Selatan lebih banyak responden yang berjenis kelamin Wanita yaitu sebesar 53\% atau sebesar 10 dari 19 Responden dibandingan responden yang berjenis kelamin Pria yaitu sebesar $47 \%$ atau 9 dari 19 responden.

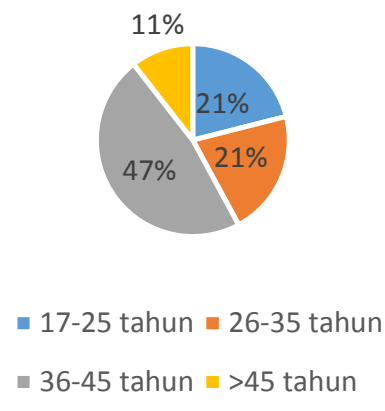

Sumber: Hasil Olah Data, 2018 Gambar 6.8 Karakteristik Responden UKM Pakaian Jadi Wilayah Jakarta Selatan Berdasarkan Jenis Kelamin Usia
Gambar 6.8 di atas menunjukan bahwa jumlah responden berdasarkan tingkatan usia dikelompokan menjadi 4 kategori yaitu: usia 17-25 tahun sebanyak 4 orang (21\%), usia 26-35 tahun sebanyak 4 orang (21\%), usia 36-45 tahun sebanyak 9 orang (47\%) dan usia $>45$ tahun sebanyak 2 orang (11\%). Sehingga responden yang berusia 36-45 tahun lebih mendominasi. Dapat disimpulkan bahwa usia 36-45 tahun pada wilayah Jakarta Selatan dalam hal responden UKM Pakaian jadi.

\section{E. UKM Pakaian Jadi Wilayah Jakarta Pusat}

Responden dalam penelitian ini dikelompokkan menjadi beberapa lokasi yaitu Pasar Gundul, Abdul Gani, Palmerah dan Cempaka Sari . Masing-masing 2 responden setiap lokasi binaan, responden yang dituju adalah Pemilik,Konsumen, Pegawai Lokbin, Kadis Wilayah, dan Kadis Provinsi. Sehingga responden yang diperoleh pada wilayah Jakarta Pusat sebanyak 24 responden yang memiliki karakteristik sebagai berikut: 


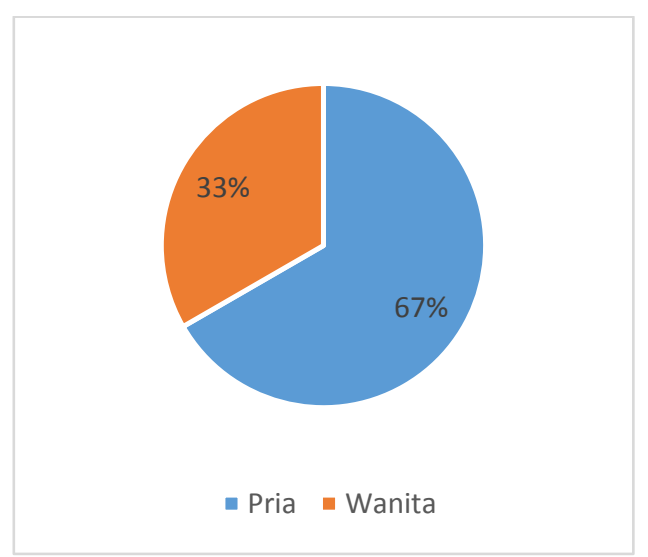

Sumber: Hasil Olah Data, 2018 Gambar 6.9 Karakteristik Responden UKM Pakaian Jadi Wilayah Jakarta Pusat Berdasarkan Jenis Kelamin

$\begin{array}{ccc}\text { Gambar } & 6.9 & \text { diatas } \\ \text { menggambarkan } & \text { bahwa } & \text { UKM } \\ \text { pakaian jadi di wilayah Jakarta } & \text { Pusat } \\ \text { lebih banyak responden } & \text { yang }\end{array}$
berjenis kelamin pria yaitu sebesar $67 \%$ atau sebesar 16 dari 24 Responden dibandingan responden yang berjenis kelamin wanita yaitu sebesar $33 \%$ atau 8 dari 24 responden.

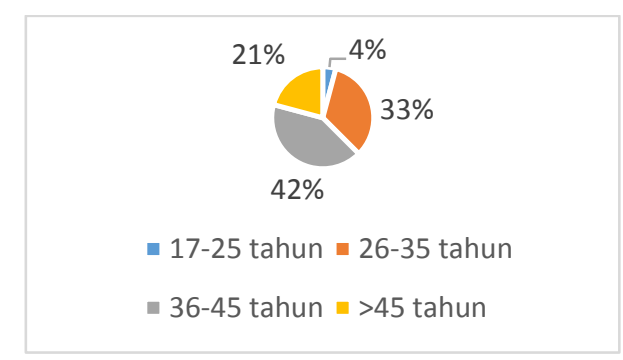

Sumber: Hasil Olah Data, 2018 Gambar 6.10 Karakteristik Responden UKM Pakaian Jadi Wilayah Jakarta Pusat Berdasarkan Jenis Kelamin Usia

Gambar 6.10 di atas menunjukan bahwa jumlah responden berdasarkan tingkatan usia dikelompokan menjadi 4 kategori yaitu: usia 17-25 tahun sebanyak 1 orang (4\%), usia 2635 tahun sebanyak 8 orang (33\%), usia 36-45 tahun sebanyak 10 orang $(42 \%)$ dan usia $>45$ tahun sebanyak 5 orang (21\%). Sehingga responden yang berusia 36-45 tahun lebih mendominasi. Dapat disimpulkan bahwa usia 36-45 tahun pada wilayah Jakarta Pusat dalam hal responden UKM Pakaian jadi.
Analisis Eksternal Dan Internal Matriks
Matriks evaluasi internal dan eksternal digunakan untuk menganalisis pengaruh lingkungan internal yang berpengaruh terhadap organisasi beberapa peluang dan ancaman. Berikut ini adalah matriks evaluasi internal pengusaha UKM Pakaian Jadi yang berada di wilayah DKI Jakarta. 
Publisher: LPPM STIE Muhammadiyah Bandung

P-ISSN: 2541-5255, E-ISSN: 2621-5306

Volume 2 Nomor 3, September - Desember 2018

Tabel 6.2 IFE Matriks Pengusaha UKM

Pakaian Jadi Di Wilayah DKI Jakarta

\begin{tabular}{|c|c|c|c|c|}
\hline Faktor Penentu & BOBOT & RATING & NLAI & RANKING \\
\hline \multicolumn{5}{|l|}{ Kekuatan } \\
\hline Sistem penyimpanan stok pakaian & 0,085 & 2,44 & 0,207 & 7 \\
\hline Pengetahuain pemilik akan incustrti & 0,077 & 3,61 & 0,280 & 1 \\
\hline Input (pembelian stok pakaian) & 0,073 & 3,22 & 0,235 & 5 \\
\hline Penawaran diskon bagi pelanggant & 0,077 & 2,92 & 0,224 & 6 \\
\hline Komunikasi pemilik langsung dengan & & & & 2 \\
\hline konsumen & 0,086 & 3,01 & 0,259 & \\
\hline Kemudahan mencari pegawai & 0,076 & 3,19 & 0,242 & 4 \\
\hline Diferensiass produl & 0,079 & 3,14 & 0,249 & 3 \\
\hline Jumlah A & 0,553 & & 1,696 & \\
\hline \multicolumn{5}{|l|}{ Kelemahan } \\
\hline Permodalan & 0,074 & 3,21 & 0,237 & 1 \\
\hline Keputusan pembiayaan (pilihan permodalan) & 0,074 & 3,07 & 0,227 & $\frac{2}{2}$ \\
\hline Keputusann Investasi (lokasi) & 0,073 & 3,06 & 0,224 & 3 \\
\hline Pengetahuan marketing karyawan yang rendah & 0,072 & 2,47 & 0,177 & 6 \\
\hline Pelatihihan karyawant & 0,072 & 2,76 & 0,200 & 4 \\
\hline Penetapan harga yang kurang tepat & 0,082 & 2,41 & 0,197 & 5 \\
\hline Jumlah B & 0,447 & & 1,261 & \\
\hline Total (Jumlah A + Jumlah B) & 1 & & 2,957 & \\
\hline
\end{tabular}

Tabel 6.3 EFE Matriks Pengusaha UKM

Pakaian Jadi Di Wilayah DKI Jakarta

\begin{tabular}{|c|c|c|c|c|}
\hline Faktor Penentu & ВОВОТ & RATING & NiLAI & RANKING \\
\hline Peluang & & & & \\
\hline 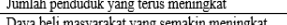 & \begin{tabular}{|c|c|c|}
0,058 \\
0,062
\end{tabular} & 2,81 & 0,162 & \\
\hline 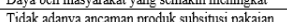 & 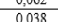 & $\frac{, 10}{271}$ & \begin{tabular}{|l|l|l|l|l|l|l|}
0,103 \\
\end{tabular} & $\frac{2}{7}$ \\
\hline Toko online sebagai plihan saluran distribusi & 0,063 & 2,99 & \begin{tabular}{|lll}
0,189 \\
\end{tabular} & 1 \\
\hline $\begin{array}{l}\text { Karakteristik unik konsumen Indonesia yang } \\
\text { korsuntif }\end{array}$ & 0,057 & 2,83 & 0,163 & 5 \\
\hline $\begin{array}{l}\text { Kemampuan pelanggan dalam berkomunikasi } \\
\text { dengany teknologi terkini }\end{array}$ & 0,054 & 2,94 & 0,158 & 6 \\
\hline 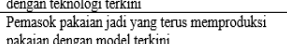 & 0,060 & 2,78 & 0,166 & 3 \\
\hline \begin{tabular}{|l|l} 
Jumlah A \\
\end{tabular} & 0,392 & & 1,111 & \\
\hline Ancraman & & & & \\
\hline $\begin{array}{l}\text { Produk impor pesaing dengan harga yang lebih } \\
\text { murah }\end{array}$ & 0,057 & 2,83 & 0,162 & 2 \\
\hline $\begin{array}{l}\text { Produk impor pesaing dengan kualitas yang lebih } \\
\text { baik }\end{array}$ & 0,063 & 2,84 & 0,180 & 1 \\
\hline $\begin{array}{l}\text { Odik } \\
\text { Skala Ekonomis }\end{array}$ & 0,057 & 2,65 & 0,151 & 5 \\
\hline Biaya peralihan ke & 0,054 & 2,66 & 0,144 & 8 \\
\hline an harga & \begin{tabular}{|l|l|l|}
0,054 \\
\end{tabular} & 2,71 & 0,147 & 7 \\
\hline $\begin{array}{l}\text { Kemampuan pelanggan dalam menuntut } \\
\text { peningkatan pelayanana }\end{array}$ & 0,042 & 3,55 & 0,150 & 6 \\
\hline 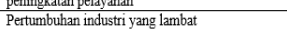 & 0,054 & 2,41 & \begin{tabular}{|l}
0,129 \\
\end{tabular} & 10 \\
\hline Jumlah pesaing yang semakin bestambah & 0,054 & 2,94 & 0,158 & 4 \\
\hline \begin{tabular}{|l} 
Perebutan posisia \\
\end{tabular} & 0,037 & 3,08 & 0,113 & 12 \\
\hline Strattegi & \begin{tabular}{|l|}
0,036 \\
\end{tabular} & 3,25 & 0,118 & 11 \\
\hline Kapasit & 0,05 & & 0,162 & \\
\hline \begin{tabular}{|l} 
Kapastisas pre \\
Hambatan kc \\
\end{tabular} & \begin{tabular}{|l|l|}
0,051 \\
0,050 \\
\end{tabular} & $\frac{3,18}{2,63}$ & & $\frac{3}{9}$ \\
\hline \begin{tabular}{|l|l} 
Mammoatan B \\
Jumlah B
\end{tabular} & \begin{tabular}{|l|l|}
0,6008 \\
0,608
\end{tabular} & & \begin{tabular}{|l|l|}
0,131 \\
1,744 \\
\end{tabular} & \\
\hline & & & & \\
\hline
\end{tabular}

\section{Tahap Analisis}

Berdasarkan perhitungan IFE dan EFE pada 6.2 dan 6.3 di atas, maka diperoleh koordinat analisis internal serta koordinat analisis eksternal yaitu $(0,217 ;-0,816)$ adapun nilai koordinat tersebut diperoleh berdasarkan perhitungan sebagai berikut:

a. Koordinat Analisis Internal
Koordinat analisis internal ini diperoleh dengan merata-ratanya hasil pengurangan skor total kekuatan dengan skor total kelemahan. Adapun perhitungan koordinat analisis internal adalah sebagai berikut:

$$
\begin{aligned}
& =\frac{(\text { skor total kekuatan-skor total kelemahan })}{2} \\
& =\frac{(1,696-1.261)}{2}=0,217
\end{aligned}
$$

b. Koordinat Analisis Eksternal

Koordinat analisis eksternal ini diperoleh dengan merata-ratanya hasil pengurangan skor total peluang dengan skor total ancaman. Adapun perhitungan koordinat analisis eksternal adalah sebagai berikut:

$$
\begin{aligned}
& =\frac{(\text { skor total peluang-skor total ancaman })}{2} \\
& =\frac{(1,111-1.744)}{2} \\
& =-0.316
\end{aligned}
$$

Koordinat tersebut kemudian dimasukkan kedalam diagram matriks grand strategy (GS). Sehingga terlihat bahwa berdasarkan koordinat di atas, posisi usaha UKM Pakaian Jadi DKI Jakarta masuk pada kuadran III yang memiliki kategori diversifikasi. Adapun matriks grand strategy (GS) yang menggambarkan posisi UKM 
Publisher: LPPM STIE Muhammadiyah Bandung

P-ISSN: 2541-5255, E-ISSN: 2621-5306

Volume 2 Nomor 3, September - Desember 2018

Pakaian Jadi DKI Jakarta dapat dilihat pada gambar berikut:

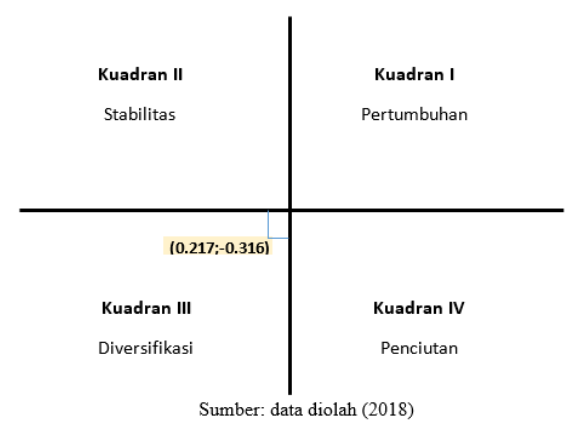

Sumber: data diolah (2018)

Gambar 6.11. Matriks Grand Strategy

(GS), Posisi Pengrajin UKM Pakaian Jadi DKI Jakarta

Diagram diatas kemudian dilengkapi pula dengan perhitungan posisi titik masing-masing kuadran beserta luas matriks dari masingmasing kuadran sebagai berikut:

Tabel 6.4 Ranking Kuadran Berdasarkan Posisi Titik Serta Luas Matriks

\begin{tabular}{|c|c|c|c|c|}
\hline Kuadran & Posisi Titik & Luas Matrix & Ranking & Prioritas \\
\hline I / SO & $(1,696 ; 1,663)$ & 2,820 & 2 & Pertumbuhan \\
\hline II / WO & $(1,261 ; 1,663)$ & 2,099 & 4 & Bertahan \\
\hline III / WT & $(1,261 ; 1,744)$ & 2,199 & 3 & Penciutan \\
\hline IV / ST & $(1,696 ; 1,744)$ & 2,958 & 1 & Diversifikasi \\
\hline
\end{tabular}

Dari pengolahan data untuk mengetahui luas matrik dan prioritas strategi pada Tabel di atas, maka diperoleh hasil luas matrik terbesar pada kuadran IV dengan luas matrik 2.958, namun perlu diperhatikan juga bahwa luas matrik pada kuadran I juga memiliki luas matrik yang cukup diperhitungkan yaitu 2.820 . Uraian mengenai posisi ranking luas matrik kuadran pada Tabel di atas antara lain:

- Ranking ke 1 : Pada kuadran ke IV dengan luas matrik 2.958

- Ranking ke 2 : Pada kuadran I dengan luas matrik 2.820

- Ranking ke 3 : Pada kuadran III dengan luas matrik 2,199

- Ranking ke 4 : Pada kuadran II dengan luas matrik 2,099

Berdasarkan posisi koordinat yang terlihat pada gambar serta luas matriks pada tabel diatas, maka alternatif strategi yang tepat bagi Pengrajin UKM Pakaian Jadi Di DKI Jakarta adalah alternatif strategi pada kuadran ke IV yaitu strategi strenghthreat (ST), atau dengan kata lain adalah strategi yang digunakan untuk mengatasi ancaman serta memperbaiki kekuatan yang dimiliki pengrajin UKM Pakaian Jadi di DKI Jakarta dengan melakukan diversifikasi seperti menambah produk untuk melengkapi produk yang sudah dijual (diversifikasi konsentris), mengembangkan produk bagi pelanggan baru (diversifikasi horizontal) atau menambahkan produk baru untuk pelanggan baru (diversifikasi konglomerat) 


\section{Analisis AHP}

Bagian terpenting dari proses analisis adalah 3 (tiga) tahapan berikut:

- Tujuan analisis dalam penelitian ini yaitu Strategi diversifikasi bagi UKM Pakaian Jadi di DKI jakarta

- Kriteria dalam penelitian itu yaitu Kekuatan, Kelemahan, Peluang, dan Ancaman

- Alternatif pilihan yang digunakan dalam penelitian ini yaitu diversifikasi konsentris, diversifikasi horizontal dan diversifikasi konglomerat

Informasi yang ada kemudian di-sintesis untuk menentukan peringkat relatif dari alternatif pilihan yang ada. Kriteria dari quantitative dapat diperbandingkan menggunakan informed judgement untuk menghitung bobot dan prioritas.

Hal ini dapat dilakukan dengan judgement untuk menentukan peringkat dari kriteria. Dalam sebuah sistem berbasis AHP, judgement ini diberikan oleh user pengguna sistem dan dilakukan pada saat user bermaksud melakukan proses AHP dan melihat rekomendasi.dengan kriteria perbandingan sebagai berikut:

1. Peluang 4 kali lebih penting dari kekuatan

2. Kekuatan 2 kali lebih penting dari ancaman

3. Kekuatan 3 kali lebih penting dari kelemahan

4. Ancaman 2 kali lebih penting dari kelemahan

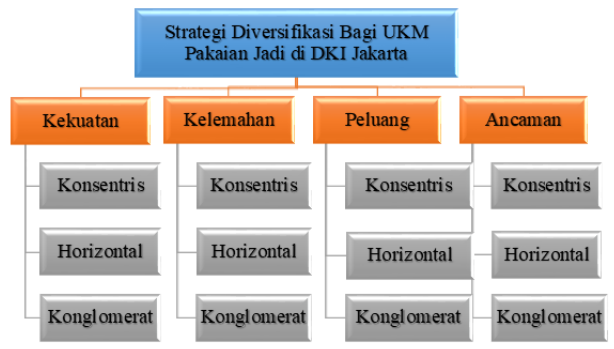

Gambar 6.12 Pohon Tujuan Analisis AHP beserta Kriteria dan Alternatif Pilihan

Berikut dibawah ini merupakan perhitungan metode AHP:

- Tahap1. Membuat Tabel Perbandingan Kriteria Yang Telah Disesuaikan Dengan Ketatntuan Peneliti Diatas

Dari judgement di atas bisa dibuatkan tabel perbandingan berpasangan sebagai berikut:

Tabel 6.5. Perbandingan Kriteria

\begin{tabular}{|l|c|c|c|c|}
\hline & $\begin{array}{c}\text { Keku } \\
\text { atan }\end{array}$ & $\begin{array}{c}\text { Kelem } \\
\text { ahan }\end{array}$ & $\begin{array}{c}\text { Pelu } \\
\text { ang }\end{array}$ & $\begin{array}{c}\text { Anca } \\
\text { man }\end{array}$ \\
\hline $\begin{array}{l}\text { Kekua } \\
\text { tan }\end{array}$ & $1 / 1$ & $3 / 1$ & $1 / 4$ & $2 / 1$ \\
\hline $\begin{array}{l}\text { Kelem } \\
\text { ahan }\end{array}$ & $1 / 3$ & $1 / 1$ & $3 / 4$ & $1 / 2$ \\
\hline $\begin{array}{l}\text { Peluan } \\
\text { g }\end{array}$ & $4 / 1$ & $4 / 3$ & $1 / 1$ & $2 / 1$ \\
\hline $\begin{array}{l}\text { Ancam } \\
\text { an }\end{array}$ & $1 / 2$ & $2 / 1$ & $1 / 2$ & $1 / 1$ \\
\hline
\end{tabular}


- Tahap 2 : Melakukan Pengkuadratan Berpasangan dan Menghitung Eigenvector Pertama Dan Kedua Untuk Menormalisasikan Kriteria.

Tabel 6.6. Perhitungan Eigenvector Pertama

\begin{tabular}{|l|r|r|r|r|r|r|}
\hline & Kekuatan & Kelemahan & Peluang & Ancaman & Jumlah & $\begin{array}{c}\text { Rata-Rata/ } \\
\text { Eigenvector 1 }\end{array}$ \\
\hline Kekuatan & 4,00 & 10,33 & 3,75 & 6,00 & 24,08 & 0,245 \\
\hline Kelemahan & 3,92 & 4,00 & 1,83 & 3,17 & 12,92 & 0,131 \\
\hline Peluang & 9,44 & 18,67 & 4,00 & 12,67 & 44,78 & 0,456 \\
\hline Ancaman & 3,67 & 6,17 & 2,63 & 4,00 & 16,46 & 0,168 \\
\hline \multicolumn{5}{|c|}{ Total } \\
\hline (" perhitungan eigenvector didapat dari pengkuadratan matriks berpasangan pada tabel 9)
\end{tabular}

(* perhitungan eigenvector didapat dari pengkuadratan matriks berpasangan pada tabel diatas)

Tabel 6.7 Perhitungan Eigenvector Kedua

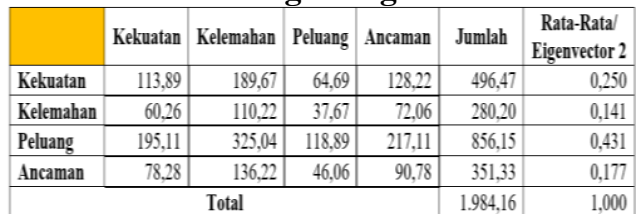
(* perhitungan eigenvector didapat dari pengkuadratan matriks berpasangan pada tabel diatas)

- Tahap 3 : Menentukan Peringkat Eigenvector Pertama Dan Kedua.

Tabel 6.8 Perbandingan Eigenvector 1 dan 2

\begin{tabular}{l|r|r|r|r|}
\hline & Eigenrector 2 & Eigenrector 1 & Jumlah (E1-E2) & \multicolumn{1}{c|}{ Peringkat } \\
\hline Kekuatan & 0,250 & 0,245 & 0,005 & 3 \\
\hline Kelemahan & 0,141 & 0,131 & 0,010 & 1 \\
\hline Peluang & 0,431 & 0,456 & $-0,025$ & 4 \\
\hline Ancaman & 0,177 & 0,168 & 0,009 & 2 \\
\hline
\end{tabular}

Kriteria yang Pertama adalah Peringkat nomor 3 terpenting

Kriteria yang Kedua adalah Peringkat nomor 1 terpenting Kriteria yang Ketiga adalah Peringkat nomor 4 terpenting, dan

Kriteria yang Keempat adalah Peringkat nomor 2 terpenting

- Tahap 4 : Melakukan Pembuatan Pohon Dengan Bobot Pada Kriterianya

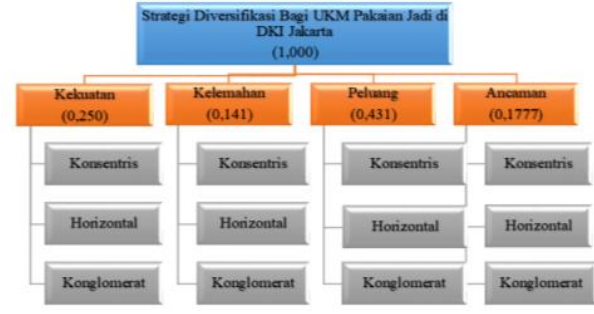

Gambar 6.13 Pohon Matriks Dengan Bobot Pada Kriteria

- Tahap 5 : Penentuan Matriks Alternatif untuk Masing-Masing Kriteria

Tabel 6.9 Matriks Ketentuan Alternative Pilihan Untuk Masing-Masing Kriteria

\begin{tabular}{|l|r|r|r|}
\hline \multicolumn{4}{|c|}{ Ketentuan } \\
\hline & $\begin{array}{c}\text { Konsen } \\
\text { tris }\end{array}$ & $\begin{array}{c}\text { Horizon } \\
\text { tal }\end{array}$ & $\begin{array}{c}\text { Konglom } \\
\text { erat }\end{array}$ \\
\hline $\begin{array}{l}\text { Konsent } \\
\text { ris }\end{array}$ & 1,00 & 3,00 & 4,00 \\
\hline $\begin{array}{l}\text { Horizont } \\
\text { al }\end{array}$ & 0,33 & 1,00 & 0,50 \\
\hline $\begin{array}{l}\text { Konglom } \\
\text { erat }\end{array}$ & 0,25 & 2,00 & 1,00 \\
\hline
\end{tabular}

Keterangan

- Kekuatan 3 kali dari

Ketentuan

- Kelemahan 1/3 kali dari kekuatan

- Peluang 4 kali dari kekuatan

- Ancaman 2 kali dari kekuatan

- Tahap 6 : Melakukan Perhitungan Eigenvector Untuk Menentukan Perangkat Dari Alternative Pilihan MasingMasing Kriteria Dengan Cara Melakukan Pengkuadratan

Tabel 6.10 Perhitungan Perkalian Kriteria-Alternatif "Kekuatan"

\begin{tabular}{|l|r|r|r|}
\hline \multicolumn{4}{|c|}{ KEKUATAN } \\
\hline & $\begin{array}{l}\text { Konse } \\
\text { ntris }\end{array}$ & $\begin{array}{l}\text { Horizo } \\
\text { ntal }\end{array}$ & $\begin{array}{l}\text { Konglo } \\
\text { merat }\end{array}$ \\
\hline $\begin{array}{l}\text { Konsent } \\
\text { ris }\end{array}$ & 1,00 & 9,00 & 12,00 \\
\hline $\begin{array}{l}\text { Horizon } \\
\text { tal }\end{array}$ & 1,00 & 1,00 & 1,50 \\
\hline $\begin{array}{l}\text { Konglo } \\
\text { merat }\end{array}$ & 0,75 & 6,00 & 1,00 \\
\hline
\end{tabular}


Keterangan: (*Matriks ketentuan pada tabel $12 \times 3$ )

Tabel 6.11 Hasil Perkalian "Kekuatan" yang di Kuadratkan

\begin{tabular}{|c|c|c|c|c|c|}
\hline \multicolumn{4}{|c|}{ Hasil Kekuatan Setelah Di Kuadratkan } & \multirow[b]{2}{*}{ Jumlah } & \multirow{2}{*}{ Rata-Rate } \\
\hline & Konsentris & Horizontal & Konglomerat & & \\
\hline Konsentis & 19,00 & 90,00 & 37,50 & 146,50 & 0,640 \\
\hline Horizontal & 3,13 & 19,00 & 15,00 & 37,13 & 0,1 \\
\hline Konglomerat & 7,50 & $18,7:$ & 19,00 & 45,25 & 0,198 \\
\hline \multicolumn{4}{|c|}{ Total } & 288,88 & 1,0 \\
\hline
\end{tabular}

Tabel 6.12 Perhitungan Perkalian

Kriteria-Alternatif "Kelemahan"

\begin{tabular}{|l|l|l|l|}
\hline \multicolumn{4}{|c|}{ KELEMAHAN } \\
\hline & $\begin{array}{l}\text { Konsen } \\
\text { tris }\end{array}$ & $\begin{array}{l}\text { Horizon } \\
\text { tal }\end{array}$ & $\begin{array}{l}\text { Konglom } \\
\text { erat }\end{array}$ \\
\hline $\begin{array}{l}\text { Konsent } \\
\text { ris }\end{array}$ & 1,00 & 2,97 & 3,96 \\
\hline $\begin{array}{l}\text { Horizont } \\
\text { al }\end{array}$ & 0,33 & 1,00 & 0,50 \\
\hline $\begin{array}{l}\text { Konglom } \\
\text { erat }\end{array}$ & 0,25 & 1,98 & 1,00 \\
\hline
\end{tabular}

Keterangan: $(*$ Matriks kekuatan pada tabel $13 * 1 / 3$ )

Tabel 6.13 Hasil Perkalian "Kelemahan" yang di Kuadratkan

\begin{tabular}{|c|c|c|c|c|c|}
\hline \multicolumn{4}{|c|}{ Hasil Kelemahan Setelah Di Knadratkan } & \multirow{2}{*}{ Jumlah } & \multirow{2}{*}{ Rata-Rata } \\
\hline & Konsentris & Horizontal & Konglomerat & & \\
\hline Konsentris & 2,29 & 11,79 & 6,74 & 20,82 & 0,645 \\
\hline Horizontal & 0,56 & 2,29 & 1,97 & 4,82 & 0,149 \\
\hline Konglomerat & 0,98 & 3,37 & 2,29 & 6,64 & 0,206 \\
\hline \multicolumn{4}{|c|}{ Total } & 32,28 & 1,000 \\
\hline
\end{tabular}

Tabel 6.14 Perhitungan Perkalian Kriteria-Alternatif "Peluang"

\begin{tabular}{|l|r|r|r|}
\hline \multicolumn{4}{|c|}{ PELUANG } \\
\hline & $\begin{array}{l}\text { Konse } \\
\text { ntris }\end{array}$ & $\begin{array}{l}\text { Horizo } \\
\text { ntal }\end{array}$ & $\begin{array}{l}\text { Konglo } \\
\text { merat }\end{array}$ \\
\hline $\begin{array}{l}\text { Konsent } \\
\text { ris }\end{array}$ & 1,00 & 36,00 & 48,00 \\
\hline $\begin{array}{l}\text { Horizon } \\
\text { tal }\end{array}$ & 4,00 & 1,00 & 6,00 \\
\hline
\end{tabular}

\begin{tabular}{l|l|l|l|}
$\begin{array}{l}\text { Konglo } \\
\text { merat }\end{array}$ & 3,00 & 24,00 & 1,00 \\
\hline
\end{tabular} Keterangan: (*Matriks kekuatan pada tabel $13 * 4$ )

Tabel 6.15 Hasil Perkalian "Kelemahan" yang di Kuadratkan

\begin{tabular}{|c|c|c|c|c|c|}
\hline \multicolumn{4}{|c|}{ Hasil Peluang Setelah Di Kuadratkan } & \multirow{2}{*}{ Jumlah } & \multirow{2}{*}{ Rata-Rata } \\
\hline & Konsentris & Horizontal & Konglomerat & & \\
\hline Konsentris & 292,00 & $1.332,00$ & 456,00 & $2.080,00$ & 0,637 \\
\hline Horizontal & 38,00 & 292,00 & 222,00 & 552,00 & 0,169 \\
\hline Konglomerat & 111,00 & 228,00 & 292,00 & 631,00 & 0,193 \\
\hline \multicolumn{4}{|c|}{ Total } & $3.263,00$ & 1,000 \\
\hline
\end{tabular}

Tabel 6.16 Perhitungan Perkalian Kriteria-Alternatif "Ancaman"

\begin{tabular}{|l|r|r|r|}
\hline \multicolumn{4}{|c|}{ ANCAMAN } \\
\hline & $\begin{array}{l}\text { Konse } \\
\text { ntris }\end{array}$ & $\begin{array}{l}\text { Horizo } \\
\text { ntal }\end{array}$ & $\begin{array}{l}\text { Konglo } \\
\text { merat }\end{array}$ \\
\hline $\begin{array}{l}\text { Konsent } \\
\text { ris }\end{array}$ & 1,00 & 18,00 & 24,00 \\
\hline $\begin{array}{l}\text { Horizon } \\
\text { tal }\end{array}$ & 2,00 & 1,00 & 3,00 \\
\hline $\begin{array}{l}\text { Konglo } \\
\text { merat }\end{array}$ & 1,50 & 12,00 & 1,00 \\
\hline
\end{tabular}

Keterangan: (*Matriks kekuatan pada tabel $13 * 2$ )

Tabel 6.17 Hasil Perkalian "Kelemahan" yang di Kuadratkan

\begin{tabular}{|c|c|c|c|c|c|}
\hline \multicolumn{6}{|c|}{ yang ai nuauratkan } \\
\hline \multicolumn{4}{|c|}{ Hasil Ancaman Setelah Di Kuadratkan } & \multirow{2}{*}{ Jumlah } & \multirow{2}{*}{ Rata-Rata } \\
\hline & Konsentris & Horizontal & Konglomerat & & \\
\hline Konsentris & 74,00 & 342,00 & 126,00 & 542,00 & 0,638 \\
\hline Horizontal & 10,50 & 74,00 & 57,00 & 141,50 & 0,167 \\
\hline Konglomerat & 28,50 & 63,00 & 74,00 & 165,50 & 0,195 \\
\hline \multicolumn{4}{|c|}{ Total } & 849,00 & 1,000 \\
\hline
\end{tabular}

Untuk mendapatkan hasil keputusan, masing-masing bobot untuk alternatif pilihan dikalikan dengan bobot dari kriteria dalam bentuk perkalian matrik sebagai berikut: 
Publisher: LPPM STIE Muhammadiyah Bandung

P-ISSN: 2541-5255, E-ISSN: 2621-5306

Volume 2 Nomor 3, September - Desember 2018

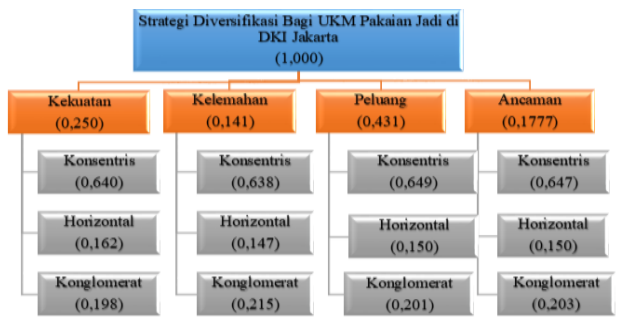

Gambar 6.14

Pohon Matriks Dengan Bobot Pada

Kriteria dan Alternatif Pilihan

Bobot dari masing-masing

alternatif pilihan pada pohon matriks tersebut kemudian dimasukkan ke dalam tabel untuk memudahkan perkalian dengan hasil eigenvector pada tabel di atas, sehingga diperoleh perhitungan seperti terlihat pada rangkaian tabel di bawah.

Tabel 6.18 Hasil Perhitungan Penentuan Pengambilan Keputusan

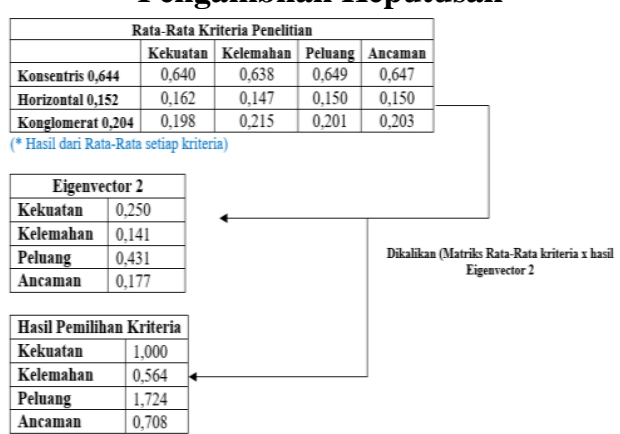

Berdasarkan tahapan-tahapan perhitungan di atas, terlihat bahwa kriteria yang paling baik untuk pengambilan keputusan ini adalah kriteria Peluang, atau dengan kata lain kriteria Peluang merupakan prioritas utama. Kemudian berdasarkan rata-rata bobot kriteria dari masing-masing alternatif diketahui pula bahwa strategi diversifikasi konsentris merupakan pilihan terbaik bagi UKM pakaian jadi di DKI Jakarta.

Dengan kata lain, strategi terbaik bagi UKM pakaian jadi di wilayah DKI Jakarta adalah menambah produk yang telah mereka miliki dengan produk-produk lain yang dapat melengkapi produk yang sudah ada, sehingga pelanggan mereka tidak perlu berpindah ke toko lain untuk melengkapi kebutuhan pakaian mereka. Terpenuhinya kebutuhan pelanggan di satu toko tertentu dapat menambah loyalitas dari pelanggan tersebut, sehingga pendapatan toko dapat meningkat karena dapat mengandalkan pelanggan setia mereka untuk membeli produk-produk terbaru yang masuk ke toko beserta kelengkapannya saat diinformasikan.

Strategi diversifikasi konsentris tersebut hendaknya dilakukan dengan memanfaatkan peluangpeluang yang ada untuk semakin memaksimalkan keuntungan, seperti menaikkan harga produk apabila 
Publisher: LPPM STIE Muhammadiyah Bandung

P-ISSN: 2541-5255, E-ISSN: 2621-5306

Volume 2 Nomor 3, September - Desember 2018

membeli satuan dan mem-bundling

produk dengan kelengkapannya serta

memberi harga miring untuk

memancing pelanggan yang

konsumtif untuk berbelanja lebih

banyak. Strategi lain yang dapat

dilakukan dengan memanfaatkan

peluang adalah menstok produk

pakaian dengan model terkini beserta

kelengkapannya, namun konsisten dengan gaya yang selama ini di miliki toko dan menginformasikan model terkini yang dimiliki kepada pelanggan dengan bantuan aplikasi seperti whatsapp atau facebook dan instagram, sehingga pelanggan tertarik membeli.

Strategi lainnya adalah dengan mengatasi kelemahan terkait karyawan. Suatu perusahaan yang ingin melaksanakan tugas dan fungsinya dengan baik, maka perusahaan tersebut akan berusaha untuk merubah para pegawainya agar mempunyai mutu serta kinerja yang baik, sehingga membuat para pegawainya lebih produktif dalam menjalankan tugas dan tanggung jawab mereka (Wandi Zulkarnaen, 2018).

\section{KESIMPULAN}

1. Gambaran UKM Pakaian Jadi di wilayah DKI Jakarta yaitu:

a. UKM Pakaian Jadi di Jakarta Barat memiliki 19 responden yang terdiri dari lokasi binaan. Lokasi wilayah yang dituju yaitu Responden dalam penelitian ini dikelompokkan menjadi beberapa lokasi yaitu Meruya Ilir, Rawa Buaya dan Bangun Nusa. Responden yang dituju adalah Pemilik, Konsumen, Pegawai Lokbin, Kadis Wilayah, dan Kadis Provinsi. karakteristik responden lebih banyak responden yang berjenis kelamin pria yaitu sebesar $63 \%$ atau sebesar 12 dari 19 Responden dibandingan responden yang berjenis kelamin wanita yaitu sebesar $37 \%$ atau 7 dari 19 responden. Responden yang berusia 36-45 tahun lebih mendominasi pada wilayah Jakarta barat dalam hal 
Publisher: LPPM STIE Muhammadiyah Bandung

P-ISSN: 2541-5255, E-ISSN: 2621-5306

Volume 2 Nomor 3, September - Desember 2018

responden UKM Pakaian jadi.

b. UKM Pakaian Jadi di Jakarta Utara memiliki 24 responden yang terdiri dari lokasi binaan. Lokasi wilayah yang dituju yaitu Responden dalam penelitian ini dikelompokkan menjadi beberapa lokasi yaitu Tipar, Lorong 103 Blok A, Lorong 103 Blok B, Lorong 103 Blok C yang dituju adalah Pemilik, Konsumen, Pegawai Lokbin, Kadis Wilayah, dan Kadis Provinsi. karakteristik responden lebih banyak responden yang berjenis kelamin pria yaitu sebesar 54\% atau sebesar 13 dari 24 Responden dibandingan responden yang berjenis kelamin wanita yaitu sebesar $46 \%$ atau 11 dari 24 responden. Responden yang berusia 26-35 tahun lebih mendominasi pada wilayah Jakarta Utara dalam hal responden UKM Pakaian jadi.

c. UKM Pakaian Jadi di Jakarta Tim ur memiliki 29 responden yang terdiri dari lokasi binaan. Lokasi wilayah yang dituju yaitu Responden dalam penelitian ini dikelompokkan menjadi beberapa lokasi yaitu Cililitan, Kramat Jati, Jalan Nusa, Makasar dan Munjul yang dituju adalah Pemilik, Konsumen, Pegawai Lokbin, Kadis Wilayah, dan Kadis Provinsi. karakteristik responden lebih banyak responden yang berjenis kelamin pria yaitu sebesar $59 \%$ atau sebesar 17 dari 29 Responden dibandingan responden yang berjenis kelamin wanita yaitu sebesar $41 \%$ atau 12 dari 29 responden. responden yang berusia 36-45 tahun lebih mendominasi. Responden yang berusia 36-45 tahun lebih mendominasi pada wilayah Jakarta timur dalam hal responden UKM Pakaian jadi.

d. UKM Pakaian Jadi di Jakarta Selatan memiliki 19 responden yang terdiri dari lokasi binaan. Lokasi wilayah yang dituju yaitu Responden 
dalam penelitian ini

dikelompokkan menjadi

beberapa lokasi yaitu Muria

Dalam, Pasar Minggu dan

Bintaro yang dituju adalah

Pemilik, Konsumen, Pegawai

Lokbin, Kadis Wilayah, dan

Kadis Provinsi. karakteristik

responden lebih banyak

responden yang berjenis

kelamin Wanita yaitu sebesar

$53 \%$ atau sebesar 10 dari 19

Responden dibandingan

responden yang berjenis

kelamin Pria yaitu sebesar

$47 \%$ atau 9 dari 19

responden. Responden yang

berusia 36-45 tahun lebih

mendominasi pada wilayah

Jakarta Selatan dalam hal

responden UKM Pakaian jadi.

e. UKM Pakaian Jadi di Jakarta

Pusat memiliki 24 responden yang terdiri dari lokasi binaan. Lokasi wilayah yang dituju yaitu Responden dalam penelitian ini dikelompokkan menjadi beberapa lokasi yaitu Pasar Gundul, Abdul Gani, Palmerah dan Cempaka Sari yang dituju adalah Pemilik,
Konsumen, Pegawai Lokbin, Kadis Wilayah, dan Kadis Provinsi. karakteristik responden lebih banyak responden yang berjenis kelamin pria yaitu sebesar $67 \%$ atau sebesar 16 dari 24 Responden dibandingan responden yang berjenis kelamin wanita yaitu sebesar $33 \%$ atau 8 dari 24 responden. Responden yang berusia 36-45 tahun lebih mendominasi pada wilayah Jakarta pusat dalam hal responden UKM Pakaian jadi.

2. Untuk dapat meningkatkan UKM Pakaian Jadi di DKI Jakarta:

a. Strategi prioritas berdasarkan hasil analisa SWOT adalah strategi pada kuadran III, yaitu strategi diversifikasi.

b. Prioritas alternatif strategi diversifikasi berdasarkan hasil analisa AHP, yaitu alternatif strategi

diversifikasi

\section{konsentris.}

c. Prioritas kriteria strategi berdasarkan hasil analisa AHP, yaitu kriteria peluang. 
Publisher: LPPM STIE Muhammadiyah Bandung

P-ISSN: 2541-5255, E-ISSN: 2621-5306

Volume 2 Nomor 3, September - Desember 2018

Dengan kata lain, UKM

Pakaian Jadi di DKI Jakarta perlu menerapkan strategi diversifikasi konsentris, yaitu menambah produk yang telah mereka miliki dengan produk-produk lain yang dapat melengkapi produk yang sudah ada. Strategi ini perlu dilaksanakan dengan memanfaatkan peluang yang ada, seperti: Daya beli masyarakat yang semakin meningkat, Toko online sebagai pilihan saluran distribusi, Karakteristik unik konsumen Indonesia yang konsumtif, Kemampuan pelanggan dalam berkomunikasi dengan teknologi terkini, Pemasok pakaian jadi yang terus memproduksi pakaian dengan model terkini.

\section{DAFTAR PUSTAKA}

Badan Pusat Statistik. (2016). Retrieved from www.bps.go.id

Daft, Richard L;. (2010). Era Baru Manajemen Buku 2 Edisi 9. Jakarta: Salemba Empat.

Elvinaro, A. (2007). Komunikasi Massa Suatu Pengantar.
Bandung:

Simbiosa

Rekatama Media.

Elvinaro, A. (2010). Metode Penelitian Untuk Public Relations Kuantitatif dan Kualitatif. Bandung: Simbiosa Rekatama Media.

Fred, David R and Forest, David R;. (2015).

Strategic

Management: Concepts and Vasses 15th Edition. New Jersey: Pearson Education Inc.

Hardiyansyah dkk. (2015). Analisis Strategi Pemasaran usaha Mie Basah (Studi Kasus di PD. Lugina-Garut). Jurnal Alogarithma Sekolah Tinggi Garut, Vol. 1 No.1 ISSN. 2302-7320.

Herdiset. (2015, Januari 16). Metode dan Cara Perhitungan AHP. Retrieved from https://herdiset.wordpress.co m/2015/01/16/metode-ahpdan-cara-perhitungan-ahp/ Irham,Fahmi. (2013). Analisis Laporan Keuangan. Bandung: Alfabeta.

KEMENTERIAN KOPERASI DAN USAHA KECIL DAN MENENGAH REPUBLIK 
Publisher: LPPM STIE Muhammadiyah Bandung

P-ISSN: 2541-5255, E-ISSN: 2621-5306

Volume 2 Nomor 3, September - Desember 2018

INDONESIA. (2017, Januari

20). Data UMKM. Retrieved

from

http://www.depkop.go.id/beri

ta-informasi/data-

informasi/data-umkm/

Kusnendi. (2008). Model-Model

Persamaan Struktural. Satu

dan Multi-group Sample

dengan LISREL. Bandung:

Alfabeta.

LPPM UPN Veteran Jakarta. (2015,

Januari 18). Rencana

Strategis Universitas

Pembangunan Nasional

"Veteran" Jakarta 2015-

2019. Retrieved from

http://www.upnvj.ac.id/id/ten

tang-upn/renstra.html

Nasution dan Hidayat. (2014).

Analisis

Strategi

Pengembangan Koperasi di

Kota Medan dengan Metode

Analisis SWOT dan

Analytical Hierarchy Process

(AHP). Jurnal Ekonomi dan

Keuangan, Vol. 2 No.7.

Parasuraman, Berry dan Zeithaml. (2001). Service Quality Can

Often Make The Difference

Between a Business Success and Failure. But What Causes
Problems, and What Can Business Do To Eliminate Them? The Answers Are Here. Jornal of Marketing, 35-43.

Porter, Michael E;. (2008). Strategi

Bersaing

(Competitive

Advantage). Tangerang:

Kharisma Publishing Group.

Purnomo dan Hadi. (2017).

Pengukuran Kinerja UMKM

Menggunakan Performance

Prism, Spektrum Industri.

Jurnal Ekonomi, Vol.15 No.2

hlm. 121-255.

Rangkuti, Freddy. (2009). Strategi Promosi Yang Kreatif Edisi 1

Cetakan 1. Jakarta: Gramedia Pustaka Utama.

Retno Hemawati. (2017, Agustus 25). Harapan Dari Usaha Mikro, Kecil dan Menengah. Retrieved from Media Indonesia:

http://mediaindonesia.com/re ad/detail/119258-harapandari-usaha-mikro-kecil-danmenengah

Supriatna \& Aminah. (2014). Analisis Strategi Pengembangan Usaha kopi Luwak (Studi Kasus UMKM 
Publisher: LPPM STIE Muhammadiyah Bandung

P-ISSN: 2541-5255, E-ISSN: 2621-5306

Volume 2 Nomor 3, September - Desember 2018

Careuh Coffe Rancabali-

Kecil dan Menengah. Jakarta:

Ciwidey Bandung). Jurnal

Eko Jaya.

Manajemen dan Organisasi,

Wandi Zulkarnaen, I. D. (2018).

Vol. 5 N0.3.

THE INFLUENCE OF

Tambunan, Tulus. (2012). Usaha

WORK MOTIVATION TO

Mikro Kecil dan Menengah di

WORK ACHIEVEMENT OF

Indonesia: Isu-Isu Penting.

EMPLOYEES IN PT. ALVA

Jakarta: LP3ES.

KARYA

PERKASA

Undang-Undang RI No.20 Tahun

BANDUNG. Jurnal Ilmiah

2008. (2008). Usaha Mikro

MEA (Manajemen, Ekonomi,

\& Akuntansi), 42-62. 